\title{
Medical decision making and risky choices: psychological and medicolegal consequences of HIV and HCV contamination of blood products
}

\section{S Riva'}

$S$ Del Sordo ${ }^{2,3}$

U Genovese ${ }^{1,3}$

G Pravettoni'

'Department of Oncology and Hemato-oncology, University of Milan, Italy; ${ }^{2}$ FOLSATEC (Foundations \& Ethics of the Life Sciences) PhD School, University of Milan, Milan, Italy; ${ }^{3}$ Healthcare Accountability Lab, University of Milan, Milan, Italy
Correspondence: Silvia Riva

Department of Oncology and Hemato-

Oncology, Faculty of Medicine, University

of Milan, Via Festa del Perdono,

720122 Milan, Italy

Tel +39025 032 I240

Email silvia.rival@unimi.it
This article was published in the following Dove Press journal:

HIVIAIDS - Research and Palliative Care

24 August 2017

Number of times this article has been viewed

Aims: The overall goal of this article is to make a scientific comment about the psycho-social consequences of hemophilia patients affected by human immunodeficiency virus (HIV) and/or hepatitis $\mathrm{C}$ virus (HCV) and to point out the related medicolegal issues.

Methods: This commentary takes into account some published evidences about the current scenario of hemophilia patients infected by HIV and/or HCV who received contaminated blood products in the late 1970s through 1985.

Results: Several psychological and medicolegal consequences are related with HIV and HCV contamination of blood products. A multidisciplinary approach is needed to treat all the difficulties experienced by these patients and to ensure good clinical decisions in medical practice. Conclusion: The literature on the psychosocial functioning of hemophilia patients with human HIV and HCV infection offers a number of implications, including medicolegal issues, that can be discussed for guaranteeing a good level of care and safeguard of this group of patients. Keywords: hemophilia, viral contaminated blood products, monetary compensation, medicolegal issues, medical decision making

Thanks to technological advancements in the last 2 to 3 decades in the treatment of hemophilia, a genetic blood-clotting disorder, the life expectancy of patients has dramatically improved. ${ }^{1}$ This clinical improvement has been especially observed in relation to the new treatment for viral infections, such as HIV and hepatitis C virus (HCV). ${ }^{2,3}$ The HIV and HCV infections were a tragedy for people with hemophilia between 1979 and 1984 as a great majority of these patients were infected by iatrogenic causes because of recurrent intravenous infusions with infected blood, which were essential for their survival.,

Today, even if the clinical hallmark of this cohort of patients who are $\mathrm{HIV}^{+}$has been totally modified, their health-related quality of life (HRQL) has not increased at a constant level, with serious psychological and socioeducational repercussions, which are not always analyzed in the literature. ${ }^{6-9}$ The ability of people with hemophilia to cope with their daily-life problems such as chronic and acute pain, stress in the family, and difficulties with social relationships has an effect on their response to $\mathrm{HIV} / \mathrm{HCV}$ and an impact on their HRQL. As recent publications have shown, hemophilia patients with HIV often experience difficulties in their daily-life functioning, their intimate and close relationships, and their job and personal careers. ${ }^{10-12}$ The rate of patients with a lower level of schooling and the rate of unemployed patients are higher compared with the rate of hemophilia patients who are $\mathrm{HIV}^{-}$and with the general population. 


\section{Methods}

The overall goal of this article is to elaborate a scientific commentary about the psychosocial consequences hemophilia patients with HIV and/or HCV experience and to point out related medicolegal issues. First, we examined some published pieces of evidence on the psychological and educational consequences this cohort experiences. Second, we discussed regulatory rules introduced in Italy and other countries to prevent viral infections from contaminating blood products and to safeguard patients already transfused with virally infected blood products. Finally, we discussed potential implications for future research in health policy and decision making.

\section{Results}

\section{Psychological consequences}

Patients with hemophilia have to learn to cope with a variety of problems of daily living as a result of the disease, such as acute and chronic pain, recurrent bleeding, daily infusions, and restrictions in their social life. ${ }^{13}$ Therefore, we suppose that their reactions to HIV and HCV infection have been set against the lifelong problems associated with hemophilia. Hemophilia can be a painful condition. It is not infrequent for patients with hemophilia (whether $\mathrm{HIV}^{+}$or $\mathrm{HIV}^{-}$) to abuse alcohol and prescribed drugs to relieve their pain. ${ }^{14}$ Depression and moodiness have both been used to describe hemophilia patients, especially those who are $\mathrm{HIV}^{+}$or $\mathrm{HCV}^{+}$. It is not clear whether these reported depression and moodiness issues are related to the HIV infection stigma, or they may indeed be an early expression of infection of the central nervous system. Research results in this area are not congruent and clear. Hemophilia patients who are $\mathrm{HIV}^{+}$are known to present cognitive and neurological disorders, which, in turn, may compromise their emotional well-being. ${ }^{15}$

In addition, having a viral infection may cause feelings of anxiety and fear, with repercussions on the HRQL and general health status. Also, $\mathrm{HIV}^{+}$and $\mathrm{HCV}^{+}$patients visit a hemophilia clinic more frequently compared with those without infections, and this has a great impact on their everyday life activities. ${ }^{15,16}$ In a pilot cohort study, Riva et al observed deficits in attention, short-term memory, abstraction, and visual recognition in adult hemophilia patients with HIV. ${ }^{11}$

Another challenge that hemophilia patients with HIV and $\mathrm{HCV}$ experience is adherence to their treatment regimen. The literature suggests wide variability of adherence in this group of patients, which may be associated with several factors, including demographics (age, family income, and housing stability, etc.), availability of social support, health beliefs, presence of a caregiver, and psychosocial functioning. As may be expected, patients with greater social support, those with more economic resources, and those with fewer symptoms of distress have generally better adherence. ${ }^{17}$ By evaluating the psychological perspective, an additional aspect of adherence comes into focus. Beyond medical adherence, young adults and adults with HIV who choose to become sexually active must be concerned with adherence to safer sexual practices, both to protect themselves from reinfection with other strains of HIV and to protect their sexual partners from infection or reinfection with other strains of the virus. Associations between perceived social support and safer sexual practices have been reported, but these have not been well investigated, especially in the adult population. ${ }^{18}$ However, adolescents and young adults with HIV who took a program to improve their adherence to safer sexual practices reported greater knowledge of protective health behaviors and were more likely to take actions to reduce risky sexual behaviors. ${ }^{19}$ Interesting considerations may also be made with respect to the educational point of view. According to the literature, hemophilia patients experience a normal academic and social adaptation..$^{20}$ However, data are not always homogeneous, especially in the cohort of $\mathrm{HIV}^{+}$patients.

Previous studies have confirmed that one's educational career may be affected by the presence of the virus, which can have an impact on a person's general intellectual score. Some studies have proved that in this cohort of patients, IQ scores fell within the average range, but total reading scores were almost one standard deviation below the mean. ${ }^{21}$ Another variable that may have an impact on educational career is absenteeism. It has been found to average 27 days, indicating that absenteeism may be a significant factor in the academic and social adaptation of children with hemophilia. ${ }^{12}$

\section{Medicolegal consequences}

After the AIDS epidemic in 1981, the occurrence of viral infections (especially HIV and HCV) in patients receiving blood products prompted government agencies in developed countries to implement regulatory and surveillance rules and to conduct criminal investigations to safeguard patients who are already infected and prevent similar cases in the future..$^{22,23}$

For example, in France, some politicians were accused of delaying the implementation of blood safety measures and failing to question donors about drug use and homosexual experiences. Also, in France, the desire to use domestically obtained products led to the use of prisoners as major sources of blood until 1991. In Italy, in 1998, a civil court ruled that the Ministry of Health was responsible for the omission of 
"its duties of prudence, diligence, impartiality, and legality" by not recommending viral inactivation treatment for blood products. ${ }^{24}$ Similar criminal investigations on government officials and pharmaceutical industry leaders were held in Germany, Switzerland, and Japan..$^{23,25}$

Because of civil lawsuits, patients transfused with virally infected blood products received monetary compensation in the USA, Italy, France, Japan, Canada, and Australia. At the same time, great efforts were made to ensure the safety of blood products in developed countries, while blood safety remains a matter of concern in developing countries. ${ }^{23,26}$ Angelotta et al noticed that some countries have promoted policy support programs for HIV patients but not for HCV ones: this is because immunosuppression-related circumstances among hemophiliac patients developed shortly after transfusions with infected blood products, whereas hepatic complications resulting from $\mathrm{HCV}$, which develops after 2 or more decades from infection, are just now being diagnosed. ${ }^{25}$

In Italy, a patient infected with an $\mathrm{HIV}^{-}-$, HBV-, or HCVcontaminated blood product can receive monetary compensation in 2 ways: the "national solidarity" fund (according to law 210/1992) or the general principle of civil liability.

In February 1992, a law was promulgated (referred to as 210/1992) to provide economic indemnity for patients permanently impaired by infected (HIV, HBV, and HCV) blood products or by compulsory vaccinations. This law introduced a "social security-type intervention" in which the Italian state itself commits to provide impaired patients with economic compensation under the principle of social solidarity, hence converting the consequences of the damage into a collective responsibility. ${ }^{27}$ This system implies a public responsibility of the Ministry of Health in the production, preparation, and administration of blood products. If the designated medical commission establishes a right to indemnity, an amount of money, as provided by law, is remitted to patients or their heirs, according to the percentage of impairment assessed. Similarly, in 2002, the French government introduced a compensation system based on national solidarity, which was dispensed by the National Fund for Compensation of Medical Accidents (ONIAM), which was merged with the fund for victims of HIV infection established in 1991 and compensated patients for the damages caused by events independent of any medical malpractice.

According to the general principles of civil liability and regardless of law 210/1992, the Italian legal system also provides for the possibility of obtaining monetary compensation under the principle of civil responsibility of the single medical practitioner, the hospital, or even the Ministry of
Health, as an institution, in case of a criminal conduct, such as failing to implement controls on blood products, according to regulations and scientific progress. ${ }^{23,24}$

Comparing these 2 systems, on average, monetary compensation granted in civil lawsuits is found more generous than the economic indemnity provided by law 210/1992. In France, as well as in Italy, compensations granted by civil courts are usually more substantial than those granted by compensation funds based on social solidarity. ${ }^{28}$

Besides law 210/1992 and civil lawsuits, regardless of the causes of disabilities, the Italian state provides all disabled citizens with social, economic, and work-related benefits ex lege $118 / 1971$. In this case, economic benefits are granted to citizens with severe disabilities and low earnings. Previous studies have observed high rates of unemployment among patients with chronic illnesses, including $\mathrm{HIV}^{+}$hemophilia patients. ${ }^{11,29}$ In Italy, in case of severe disability or poor health state, a worker can be declared incapable of rendering work or capable of rendering work with limitations. Also, permits to attend medical examinations and therapies are granted to disabled workers. In any case, the Italian Constitution forbids discrimination based on health status.

\section{Future prospects and conclusion}

The cohort of hemophiliac patients infected with HIV or HCV through blood transfusions could be an interesting population to evaluate the potential source of monetary compensation (either by civil courts or by national solidarity) and its amount. Further studies should also aim to evaluate whether the source and the amount of monetary compensation can be related to different rates of unemployment or different levels of schooling. Since the HIV epidemic in hemophilia-transfused patients broke out in the 1980s and 1990s, and since hemophiliac patients generally need transfusions during childhood, infected patients during those years would now have grown into adults, and investigation on monetary compensations could be indirectly useful to retrospectively evaluate the effectiveness of "national solidarity" and social safeguard.

The literature on the psychosocial functioning of hemophilia patients with HIV and HCV infection offers a number of implications, including medicolegal issues, that can be discussed to guarantee a good level of care and protect this group of patients.

Of course, multidisciplinary communication must be encouraged, and treatment teams may include behavioral specialists who can provide education and guidance on appropriate developmental milestones and career opportunities. ${ }^{30}$ Counseling should be considered in light of the ecosystem in which the 
patient lives, for example, the degree of social support received by the family, the coping strategies employed by the patient, and the number and severity of negative life events experienced by the patient. ${ }^{31}$ This may hold particular relevance for clinical work with children and families affected by HIV. To the extent that HIV-related stressors are controllable (e.g., adherence), active or problem-focused strategies should be encouraged.

Beyond that, complete counseling should also include information about social, work-related, and potentially economic benefits, as provided by laws, to disabled and impaired patients. Information should be as thorough as possible. Moreover, as is well known, transfusion medicine deals with ethical and deontological issues with regard to clinical appropriateness, information and consent to or refusal of transfusion, safety of underage donors, and development of institutional programs of blood management. ${ }^{32}$

In certain cases, medicolegal experts could provide information and professional support with regard to these issues, including "national solidarity" funds or compensation under the criminal law system..$^{33,34}$

\section{Disclosure}

The authors report no conflicts of interest in this work.

\section{References}

1. Khleif AA, Rodriguez N, Brown D, Escobar MA. Multiple comorbid conditions among middle-aged and elderly hemophilia patients: prevalence estimates and implications for future care. J Aging Res. 2011;2011:985703.

2. Mannucci PM, Schutgens RE, Santagostino E, Mauser-Bunschoten EP. How I treat age-related morbidities in elderly persons with hemophilia. Blood. 2009;114(26):5256-5263.

3. Mangiafico L, Perja M, Fusco F, Riva S, Mago D, Gringeri A. Safety and effectiveness of raltegravir in patients with haemophilia and anti-HIV multidrug resistance. Haemophilia. 2012;18(1):108-111.

4. Yeo AE, Matsumoto A, Hisada M, Shih JW, Alter HJ, Goedert JJ. Effect of hepatitis $\mathrm{G}$ virus infection on progression of HIV infection in patients with hemophilia. Multicenter Hemophilia Cohort Study. Ann Intern Med. 2000;132(12):959-963.

5. Riva S, Pravettoni G. Infection in people with severe mental illness. Lancet Psychiatry. 2016;3(3):204.

6. Franchini M, Castaman G, Coppola A, et al; AICE Working Group. Acquired inhibitors of clotting factors: AICE recommendations for diagnosis and management. Blood Transfus. 2015;13(3):498-513.

7. Darby SC, Kan SW, Spooner RJ, et al. Mortality rates, life expectancy, and causes of death in people with hemophilia A or B in the United Kingdom who were not infected with HIV. Blood. 2007;110(3): 815-825.

8. Oakley M. Causes of death among patients with bleeding disorders receiving care at US Hemophilia Treatment Centers. October 2011December 2014. Presented at: 143rd APHA Annual Meeting and Expo (Oct. 31-Nov. 4, 2015); November 3; 2015; Chicago, IL.

9. Riva S, Oliveri S, Fioretti C, Masiero M, Pravettoni G. The role of frontal-subcortical circuitry in neuropsychological deficit of attention: hypothesis and results in two coagulation disorders. Front Hum Neurosci. 2016;10:89.
10. Riva S, Cutica I, Pravettoni G. Is there evidence for neurocognitive dysfunctions in patients with postnatal HIV infection? A review on the cohort of hemophilia patients. Front Hum Neurosci. 2014;8:470.

11. Riva S, Cutica I, Krampe C, et al. A cohort pilot study on HIV-associated neuropsychological impairments in hemophilia patients. Front Hum Neurosci. 2015;9:313.

12. Colegrove RW Jr, Huntzinger RM. Academic, behavioral, and social adaptation of boys with hemophilia/HIV disease. JPediatr Psychol. 1994;19(4): 457-473.

13. Barr RD, Saleh M, Furlong W, et al. Health status and health-related quality of life associated with hemophilia. Am J Hematol. 2002;71(3): $152-160$.

14. Rambod M, Sharif F, Molazem Z, Khair K. Pain experience in hemophilia patients: a hermeneutic phenomenological study. Int J Community Based Nurs Midwifery. 2016;4(4):309-319.

15. Wright CC, Barlow JH, Turner AP, Bancroft GV. Self-management training for people with chronic disease: an exploratory study. $\mathrm{Br} J$ Health Psychol. 2003;8(4):465-476.

16. Johnson JG, Rabkin JG, Lipsitz JD, Williams JB, Remien RH. Recurrent major depressive disorder among human immunodeficiency virus (HIV)-positive and HIV-negative intravenous drug users: findings of a 3-year longitudinal study. Compr Psychiatry. 1999;40(1):31-34.

17. Qurishi N, Kreuzberg C, Lüchters G, et al. Effect of antiretroviral therapy on liver-related mortality in patients with HIV and hepatitis C virus coinfection. Lancet. 2003;362(9397):1708-1713.

18. Laurian Y, Peynet J, Verroust F. HIV infection in sexual partners of HIV-seropositive patients with hemophilia. N Engl J Med. 1989;320(3): 183.

19. Albarracín D, Gillette JC, Earl AN, Glasman LR, Durantini MR, Ho $\mathrm{MH}$. A test of major assumptions about behavior change: a comprehensive look at the effects of passive and active HIV-prevention interventions since the beginning of the epidemic. Psychol Bull. 2005;131(6): $856-897$.

20. Siboni SM, Mannucci PM, Gringeri A, et al; Italian Association of Haemophilia Centres (AICE). Health status and quality of life of elderly persons with severe hemophilia born before the advent of modern replacement therapy. J Thromb Haemost. 2009;7(5):780-786.

21. Sirois PA, Usner DW, Hill SD, et al. Hemophilia growth and development study: relationships between neuropsychological, neurological, and MRI findings at baseline. J Pediatr Psychol. 1998;23(1): 45-56.

22. Tony D. Blood, HIV, and compensation. BMJ. 1990;300(6717):67-68.

23. Weinberg PD, Hounshell J, Sherman LA, et al. Legal, financial and public health consequences of HIV contamination of blood and blood products in the 1980s and 1990s. Ann Intern Med. 2002;136(4):312-319.

24. Simini B. Italian Health Ministry found guilty in tainted-blood product scandal. Lancet. 1998;352(9144):1916.

25. Angelotta C, McKoy JM, Fisher MJ, et al. Legal, financial, and public health consequences of transfusion-transmitted hepatitis $\mathrm{C}$ virus in persons with hemophilia. Vox Sang. 2007;93(2):159-165.

26. Thein HH, Yi Q, Heathcote EJ, Krahn MD. Prognosis of hepatitis C virus-infected Canadian post-transfusion compensation claimant cohort. J Viral Hepat. 2009;16(11):802-813.

27. Fineschi V, Cateni C, Fanetti PL, Turillazzi E. No-fault compensation for transfusion-associated hepatitis B virus, hepatitis $\mathrm{C}$ virus, and HIV infection: Italian law and the Tuscan experience. Transfusion. 1998;38(6):595-601.

28. Helleringer G. Medical malpractice and compensation in France: part II: compensation based on national solidarity. Chicago-Kent Law review. 2001;86(3):1125-1138.

29. Shaw KM, Theis KA, Self-Brown S, Roblin DW, Barker L. Chronic disease disparities by county economic status and metropolitan classification, behavioral risk factor surveillance system, 2013. Prev Chronic Dis. 2016;13:E119.

30. Riva S, Schulz P, Staffoni L, Schoeb V. Patient participation in discharge planning decisions in the frame of Primary Nursing approach: a conversation analytic study. Stud Commun Sci. 2014;14(1):61-67. 
31. Renzi C, Riva S, Masiero M, Pravettoni G. The choice dilemma in chronic hematological conditions: why choosing is not only a medical issue? A psycho-cognitive perspective. Crit Rev Oncol Hematol. 2016;99:134-140.

32. Sacchini D, Liumbruno GM, Bruno G, et al. Ethical and deontological issues in transfusion medicine. Blood Transfus. 2013;11(1):14-25.
33. Casali MB, Mobilia F, Del Sordo S, Blandino A, Genovese U. The medical malpractice in Milan-Italy. A retrospective survey on 14 years of judicial autopsies. Forensic Sci Int. 2014;242:38-43.

34. Genovese U, Del Sordo S. Should the anesthesiologist's role as "warrantor" of patients' health undergo Courts' judgements? Minerva Anestesiol. 2015;81(12):1283-1285.
HIV/AIDS - Research and Palliative Care

\section{Publish your work in this journal}

HIV/AIDS - Research and Palliative Care is an international, peerreviewed open access journal focusing on advances in research in HIV its clinical progression and management options including antiviral treatment, palliative care and public healthcare policies to control viral spread. The journal is included in PubMed. The manuscript man-

\section{Dovepress}

agement system is completely online and includes a very quick and fair peer-review system, which is all easy to use. Visit http://www.dovepress. com/testimonials.php to read real quotes from published authors. 